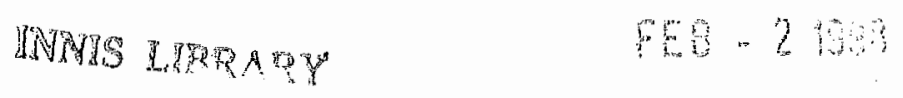

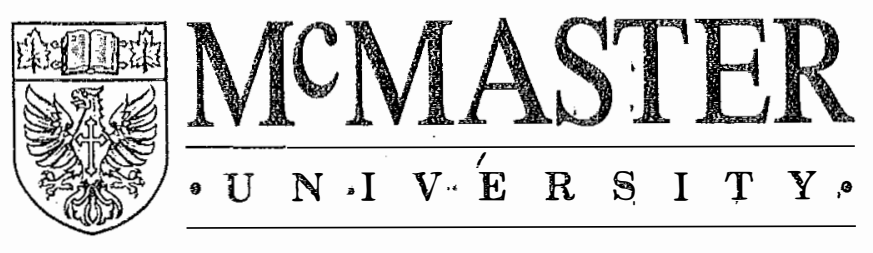

M I C H A E L G. D E G R O O T E SCHOOL OF BUSINESS

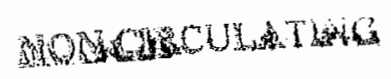

\section{RESEARCH AND WORKING PAPER SERIES}

\title{
MISSION STATEMENT RATIONALES AND ORGANIZATIONAL ALIGNMENT IN THE NOT-FOR-PROFIT HEALTHCARE SECTOR
}

\author{
By \\ Christopher K. Bart with John C. Tabone \\ Michael G. DeGroote School of Business \\ McMaster University, \\ Hamilton, Ontario, Canada
}

Working Paper \# 423

November, 1997

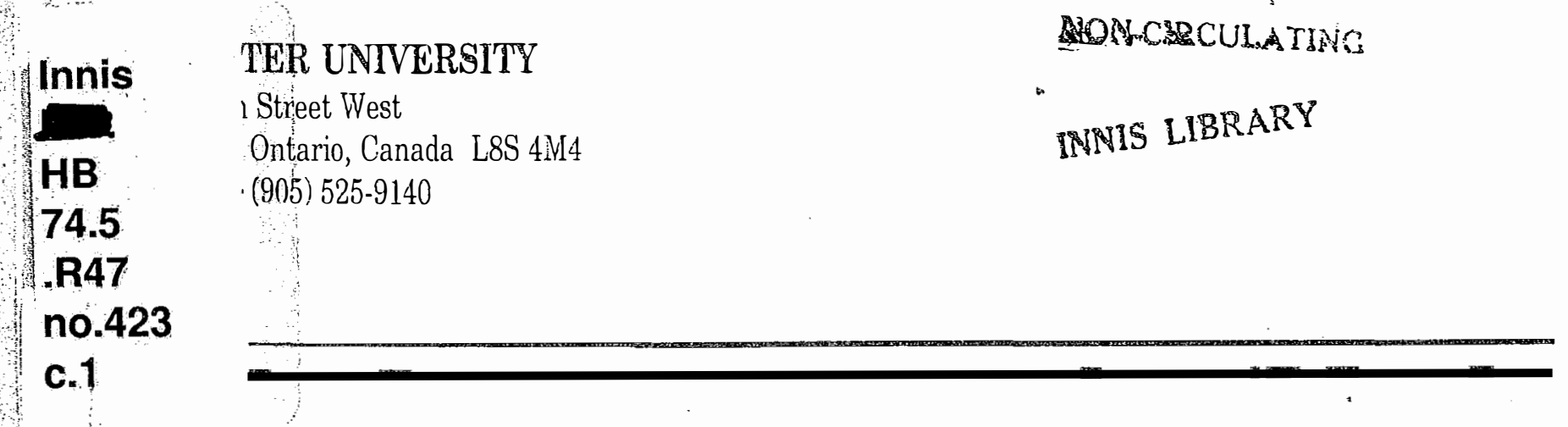


NON-CRRCULATHNG

MISSION STATEMENT RATIONALES AND ORGANIZATIONAL ALIGNMENT IN THE NOT-FOR-PROFIT HEALTHCARE SECTOR

\author{
By
}

Christopher K. Bart with John C. Tabone

Michael G. DeGroote School of Business McMaster University,

Hamilton, Ontario, Canada

Working Paper \# 423

November, 1997

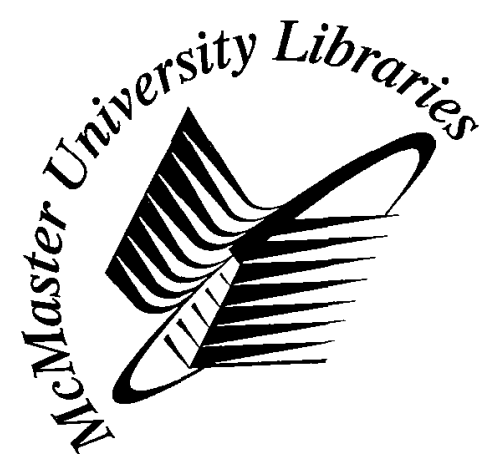




\section{Mission Statement Rationales and Organizational Alignment in the Not-for-profit Healthcare Sector}

\section{by}

Christopher K. Bart, Ph.D., C.A.

Professor of Business Policy

Michael G. DeGroote School of Business

McMaster University

Hamilton, Ontario, Canada L8S 4M4

Tele: 905-525-9140 ext. 2-3967

e-mail: bartck@mcmaster.ca

with

John C. Tabone, H.B.Comm.

MBA Candidate

Schulich School of Business

York University

c/o 256 Athenia Drive,

Stoney Creek, Ontario, Canada L8J 1T7

Tele: 416-650-2906

e-mail: tabonej@yorku.ca

(C) 1997, Christopher K. Bart, all rights reserved 


\title{
Mission Statement Rationales and Organizational Alignment in the Not-Profit Healthcare Sector
}

\begin{abstract}
This article presents the findings from a research study conducted on the use of mission statements in not-for-profit healthcare organizations. In particular, the study sought to determine if a relationship exists between the initial "rationales" which led to the creation of a mission statement and hospital performance. The findings suggest that some of the rationales for developing mission statements are indeed more important then others. Hospital administrators should, therefore, pay close attention to the forces driving the development of their organization's mission statement. The findings also suggest that mission statement alignment with organizational structures is of key importance to the mission's success.
\end{abstract}




\section{Mission Statements in the Not-for-Profit Healthcare Sector}

\section{Introduction}

In recent years, mission statements have become recognized in modern management theory as one of the cornerstones of an organization. The conclusion of most commentaries on mission statements is that they are an essential factor contributing to an organization's enduring success. This has led firms of all types (i.e., large/small, for-profit/non-profit) to develop mission statements as a key component of their strategic plans. As a result, mission statements have flourished and are, today, regarded as the number one tool used by managers worldwide (Bain and Company, 1994).

Not surprisingly, a considerable number of writings exist which suggest how managers should develop and implement their organization's mission statement. Unfortunately, there are a large number of inconsistencies in these recommendations and few are backed by any empirical evidence. The fact that there is no reliable and recognized base of research on mission statements is somewhat amazing because the virtues of having a well-articulated mission statement are extolled in almost every current management textbook. This lack of guidance has meant, in turn, that the task of formulating an appropriate mission statement can be extremely difficult - not to mention downright frustrating.

As a first step in developing a mission statement, the most basic question every manager must answer is: "Why am I doing this?" or "Why do I want to have a mission statement?" While the literature suggests several answers to this question, there has been almost no research to back these answers up. Also, none of the existing mission research has focused, even partially, on organizations in the not-for-profit healthcare sector. The primary purpose of the research presented in this paper, 
therefore, was to begin the process of exploring how mission statements are developed and used in health care organizations as well as the role they play in organizational success. In this regard, our first objective was to find out the reasons (or "drivers") leading to the formulation of hospital mission statements in the first place and, then, to determine which ones appear to be leading to the most effective outcomes.

A second objective of this research was to determine the extent to which managers have aligned their hospital's organizational structure with their mission statement. This is because a mission statement which is not in sync with an organization's formal structure is often regarded as being of little value. (Bart and Baetz, 1997; Bart 1986 and 1988; Byars, 1984; Thompson and Strickland, 1996; Galbraith and Kazanjian, 1986) In fact, a long history of research has found that the choice of organizational arrangements makes a difference in the achievement of an organizations's strategy. (Lawrence and Lorsch, 1967; Rumelt, 1974) This research therefore sought to determine which aspects of a hospitals' formal structure were most important in keeping attuned to its mission statement.

\section{Theoretical Background}

Definition. A mission statement is a written, formal document which attempts to capture an organization's unique and enduring purpose and practices. (Bart 1996a; Bart 1996b; Bart 1997a; Byers, 1984 and 1987; Campbell, 1989 and 1993; Campbell \& Yeung, 1991; Daft \& Fitzgerald, 1992; David, 1993; David, 1989; Germaine and Cooper, 1990; Higgens \& Fincze, 1989; Hunger \& Wheeler, 1993; Ireland \& Hitt, 1992; Johnson, Scholes \& Sexty, 1989; Klemm, Sanderson \& 
Luffman, 1991; McGinnis, 1981; Medley, 1992; Rue \& Holland, 1988; Thompson and Strickland, 1996) In doing so it should answer some really fundamental questions such as "Why does this organization exist?", and "What does this organization want to achieve?" A mission statement should find itself central to every firm's strategy. Unlike objectives and other strategic statements, mission statements should be: enduring, (i.e., they should not have a time frame); passionate (i.e., they should be emotionally charged); and lacking specific quantitative measurements (i.e., financial goals).

Mission Statement Rationales. Traditionally, the major rationales associated with mission statements have been cited as:

a. Providing a more focused basis for allocating resources (Ireland and Hitt, 1992; King and Cleland, 1979; Gibson et al., 1990);

b. Motivating and inspiring members throughout the organization to achieve a common goal or purpose (Campbell, 1989 and 1993; Collins and Porras, 1991; Daniel, 1992; Germain \& Cooper, 1990; Javidan, 1991; Ireland and Hitt, 1992; Klemm et al., 1991; King and Cleland, 1979; El-Namaki, 1992; Wilson, 1992); and

c. Creating a balance between the competing interest of stakeholders (i.e., customers, society, shareholders and employees) (Klemm et al., 1991).

More recently the literature has suggested further reasons for developing a mission statement. These include:

- Refocusing an organization during a crisis (Campbell and Yeung, 1991);

- Creating behavior standards (Campbell and Yeung, 1991; Bart 1996a and 1996b);

- Providing a common purpose or direction (Campbell, 1991; Klemm et al., 1991; Ireland and 
Hitt, 1991);

$\checkmark \quad$ Defining the scope of the business (Campbell, 1991; Klemm et al., 1991; Ireland and Hitt, 1991);

$\checkmark \quad$ Allowing the CEO to assert control over the organization (Klemm et al., 1991); and

- Developing shared values or culture within the organization (Campbell, 1991; Pearce and David, 1987; Ireland and Hitt, 1991);

Whatever the rationale, the overarching purpose for developing a mission statement is to improve overall firm performance.

There exists very little empirical research, however, which suggests what the best purpose or rationale for developing a mission statement should be. The focus of past mission statement research studies has been primarily on analyzing the content and characteristics of mission statements. These studies (David, 1989; Want, 1986; Campbell and Yeung, 1991; Gibson, Newton \& Cochrane, 1990) have simply looked at the frequency with which various components have appeared in a sample of mission statements. (e.g., values, purpose, goals, behavior standards, etc.) But, this research made no explicit attempt to link mission statement characteristics to firm performance. And it did not generally examine or probe for the purposes behind the development of the mission statements.

Only recently has there been some research conducted which explicitly explores the rationales for developing a mission statement. Bart (1996b), for instance, conducted a study of mission statements in seventy-five large advanced technology firms, and he examined the impact of ten potential "mission statement drivers" (or rationales) on selected measures of firm performance. He found few and mostly inconsistent relationships between the mission statement rationales and his measures of financial performance. However, Bart's research found a fairly strong and consistent 
relationship between eight of the rationales and the degree of influence which the mission statement had on employee behavior. Mission statements developed for these eight drivers were therefore more likely to have an influence on employee behavior than ones which were not. These performance enhancing drivers were: to provide a sense of purpose; to give CEO's greater control; to define behavior standards; to enable employees to identify with their organization; to give greater recognition to the interests of external stakeholders; to inspire/motivate employees; to refocus the organization during a crisis; and to improve the resource allocation process. "Defining the organization's scope of business" and "developing the organization's culture" were the only two drivers whose use did not seem to influence employees.

In another study, Bart (1997a) examined the use and impact of the ten mission statement rationales in industrial firms. Again, he found that managers appeared to use seven (out of 10) drivers more often when developing their organization's mission statement. (i.e., used by more then $50 \%$ of the firms). But, these hi-influence drivers weredifferent from his study of hi-tech organizations. These hi-use industrial firmdrivers were: providing a common purpose; defining the business scope; setting behavior standards; helping employees identify with their firms; creating shared values; emphasizing the interest of external stakeholders; and inspiring/motivating employees. The low-use drivers were: allowing the $\mathrm{CEO}$ to assert control; refocusing the organization in crisis, and improving resource allocation.

In examining the impact of these drivers on firm performance, however, Bart found results which were similar to his study of high-tech firms. i.e., The missions drivers' (significant and positive) relationship with performance existed only when measuring "influence on employee behavior" and not for any of the financial measures. The performance enhancing drivers were: 
providing a common purpose; allowing the $\mathrm{CEO}$ to exert control; including the interests of external stakeholders; inspiring/motivating employees; refocusing the organization during a crisis; and improving resource allocation.

In yet another study, Bart (1997b) compared the frequency with which ten mission statement drivers were used in innovative and non-innovative firms . (He did not investigate their relationship with performance.) Bart found that certain rationales were more prevalent in innovative firms than in non-innovative ones. The dominant drivers distinguishing innovative firms were to: establish a common purpose; create shared values; ensure the interests of external stakeholders are not ignored; and to inspire/motivate employees.

Thus, while it appears that there are some core rationales which appear to apply to almost any organization, some also are firm-type specific. To date, no such study has been conducted with respect to not-for-profit healthcare organizations. In fact, Gibson, Newton, and Cochrane (1990) are the only researchers who have investigated the nature of mission statements in hospitals to any extent. Their research, however, was limited to simple frequency analyses and they did not examine why hospital managers had developed their organization's mission statements. Given that some mission statement rationales appear to vary with respect to industry, it would therefore be useful to know which ones appear to have greater impact (if any at all) in the case of healthcare organizations

Mission statement alignment with structural components. The current literature claims that in order for any strategy to be successfully implemented, management systems and processes must be consistent with and reinforce the strategy itself. (Bart, 1986; Byars, 1984; Thompson and Strickland, 1996; Galbraith and Kazanjian, 1986; Hamermesh, 1982) This suggests that for a mission 
statement to be effective, it must be aligned with a firm's key organizational structures; that there should be a "fit" between the mission and a firm's major systems and processes. (i.e., job design, strategic planning system, operating planning system, budgeting system, performance evaluation criteria, leadership styles, etc.) In a study of the mission/structure alignment relationship in 88 North American corporations, Bart (1997c) verified this conjecture. Bart found a strong correlation between virtually every aspect of the firms' organizational structure and its achievement of the mission. Surprisingly, very few managers of the firms in his study had totally aligned their business' organizational components with their mission statement. No studies, however, have attempted to examine the impact of mission/structure alignment on hospital performance. As a result, there is currently no guidance for managers in determining the key structural components which they must align with their hospital's mission statement to enhance performance.

Mission Statements in Not-for-profit Hospitals. Mission statements are particularly important in the not-for-profit healthcare sector. In a for-profit business, there is an underlying purpose "to make money." This is not the case for non profits however. According to Drucker (1989), "Not-for-profit organizations need management because they do not have a bottom line." Thus, a mission statement should help to keep not-for-profit organizations, such as hospitals, focused and, in so doing, act as a "surrogate bottom line."

There is currently, an especially great need for a not-for-profit hospital to develop and implement a mission statement. The tightened budgets, the new mandates, and the changing regulations that have accompanied the shift toward managed healthcare has made mission statements a particularly important tool in the not-for-profit health care sector. A well-articulated mission statement can help make hospitals more efficient and thus, enable it to survive these changes.

$$
\text { Page -9- }
$$


None of the previous research has examined the impact of mission statement rationales in the context of not-for-profit businesses - let alone hospitals. Nevertheless, it is expected that mission statements (and the processes by which they are formulated) should be substantially different in the not-for-profit sector. This is because mission statements appear to serve a different set of purposes in not-for-profits as opposed to other types of organizations. The different and changing regulations under which hospitals operate also imply that the rationale(s) for developing a mission should differ.

\section{Research Questions}

The heightened importance of mission statements in the not-for-profit healthcare sector (combined with the lack of guidance available to managers on how to develop and implement them) led us to develop this research project. With all the writings encouraging the development and use of missions, healthcare managers should have as much direction as possible in formulating their organization's mission statement. The specific questions addressed by this research were as follows:

- What are the primary "drivers" or "rationales" for developing a mission statement in the notfor-profit healthcare sector?

- To what extent have healthcare organizations been successful in achieving the rationales which guided the development of their mission statements?

- What impact do different mission statement rationales have on hospital performance, if any? i.e., are there right and wrong reasons for developing a mission statement?

- To what extent do managers in the not-for-profit healthcare sector align their organization's formal structure, systems and processes with their mission?

- Does the degree of alignment between an organization's mission statement and its formal Page -10- 
structure have any impact on performance?

Are there specific structural components whose alignment with an organization's mission statement is more important than others?

\section{Research Method}

\section{Sample Selection and Size}

A questionnaire was mailed out to the top manager (i.e., CEO/President/Executive Director/Administrator) of 849 these hospitals which listed in the "Guide to Canadian Healthcare Facilities 1995-1996" and which were identified as having a minimum budget of two million dollars. One hundred and three completed questionnaires were returned representing a response rate of 12.1 percent. At first glance, this response level may appear to be low, but it is important to note that the sample surveyed actually represented the entire population of hospitals. Of the responses received, 60.2 percent were the "top manager" within the hospital and the remainder were all senior level executives.

Unfortunately, the sampling method restricts the claims which can be made about the representativeness of the findings as they apply to hospitals of all sizes. The respondents, however, were all medium to large, not-for-profit, healthcare institutions and it is therefore expected that the results would be applicable to similarly sized not-for-profit healthcare institutions across North America. Table 1 presents some key operating statistics for the hospitals in this study. 


\section{Operationalizing Mission Statement Rationales}

The mission statement "drivers" were operationalized through a literature review. In a literature survey conducted by Bart (1996b \& 1997a), a list of ten rationales was identified which others had indicated or inferred as potentially being a significant reason for developing a mission statement. We reformulated these rationales into our own questionnaire. The mission statement rationales included were:

$\checkmark$ to provide a common direction/unity of purpose transcending individual and departmental needs (Drucker, 1973; King and Cleland, 1979; Want, 1986, Campbell and Yeung, 1991; Klemm et al., 1991; Ireland and Hitt, 1992);

- to define the organization's scope of business operations / activities (Drucker, 1973; Campbell and Yeung, 1991; Klemm et al., 1991; Ireland and Hitt, 1991);

- to enable top managers (especially the CEO) to assert authority over the firm's activities (Klemm et al., 1991);

$\checkmark \quad$ to create standards of behavior for the organization's members (Want, 1986; Campbell and Yeung, 1991; Bart, 1996a and 1996b);

to enable employees to identify with the organization's purpose / direction and to encourage those who do not to leave (King and Cleland, 1979);

to promote a sense of shared expectations among all levels of employees, thereby building a strong corporate culture (i.e., shared values) (Want, 1986; Pearce and David, 1987); Campbell and Yeung, 1991; Ireland and Hitt, 1992);

- to ensure that the interests of key external stakeholders (e.g., government, customers, suppliers) are not ignored (Klemm et al., 1991); 
$\checkmark \quad$ to motivate/inspire organization members (Campbell, 1989 and 1993; Collins and Porras, 1991; Daniel, 1992; German and Cooper, 1990, Javidan, 1991; Ireland and Hitt, 1992; Klemm et al., 1991; King and Cleland, 1979; El-Namaki, 1992; Wilson, 1992); to refocus the organization during a crisis (Campbell and Yeung, 1991); and to provide a basis for allocating resources (Ireland and Hitt, 1992; King and Clelland, 1979).

\section{Operationalizing Organizational Components}

The strategy and business policy literature have long argued the need for effective organizational arrangements to implement corporate strategies. (Hamermesh, 1982; Lawrence and Lorsch, 1967, Rumelt, 1974) This research, however, is the first study which has specifically attempted to assess the impact of aligning an organization's systems and processes with its mission. Fourteen components which the literature has defined as being important systems and processes to align with an organization's strategy (Hamermesh, 1982; Mintzberg, 1979, Galbraith and Kanzanjian, 1986; Thompson and Strickland, 1996) were included in this study. These were:

- organizational structure / design

$\checkmark \quad$ job descriptions/job design

$\checkmark \quad$ strategic planning system

$\checkmark \quad$ operating planning system

$\checkmark \quad$ budgeting system

performance evaluation criteria

$\checkmark \quad$ types of rewards

$\checkmark \quad$ recruitment system

Page -13- 
$\checkmark \quad$ promotion system

$\checkmark \quad$ training / organizational development

$\checkmark \quad$ leadership styles

$\checkmark \quad$ general business objectives and targets

$\checkmark \quad$ management information systems

$\checkmark \quad$ choice of technology

\section{Data Collection}

Using our operational definitions of potential mission statement rationales and organizational dimensions a questionnaire was developed (and pretested). This questionnaire was designed to measure: (a) the degree to which a hospital's mission statement was developed for and achieving each of the ten rationales; and (b) the extent to which managers were pleased/satisfied their current organizational arrangements (i.e., the fourteen structural components) and the degree of alignment between these components and the hospital's mission statement. (Note: although it is recognized that the actual reasons why a firm has developed its mission statement may vary significantly from the managers' perceptions, exploring such differences has been left for a future study.)

In order to measure mission statement rationales, hospital administrators were asked to indicate the degree to which their organization's current mission statement was developed for each of the ten purposes identified above. ( $1=$ not at all; $5=$ to the greatest possible extent) Hospital administrators were also asked to indicate the extent to which each of the fourteen structural components listed earlier was aligned with their organization's current mission statement. (1=not at all; $5=$ to the greatest possible extent)

$$
\text { Page -14- }
$$


Note that all of these questions have been asked in some recent mission statement studies. (Bart, 1996b, 1997a, 1997b, \& 1997c) However, none of these questions has been asked previously of managers in the not-for-profit healthcare sector. The results obtained should, therefore, be considered somewhat exploratory in nature.

\section{Outcome Measures}

Five outcome measures were used to assess the impact of the mission statement rationales and alignment with performance. These were: (1) managers' satisfaction with the current mission statement (Bart, 1997b; Bart and Baetz, 1997); (2) the degree to which the mission statement influences the behavior of the respondent (Bart, 1997); (3) the extent to which the mission statement appears to influence the behavior of members throughout the organization (Bart, 1997; Bart, 1996b; Bart, 1996c, Bart and Baetz, 1997); (4) the degree to which hospital members are committed to the mission statement (Bart, 1997); and (5) manager's satisfaction with the hospital's overall financial performance. Hospital administrators were asked to rate each of these performance measures on a 10-point scale. $(0=$ not at all, $9=$ to the greatest possible extent $)$.

It should be pointed out that the measure "satisfaction with overall financial performance" is new to this study. It was added in order to measure "bottom line" financial performance. It would have been preferable to use some independently collected measures of financial performance, such as profitability or sales. But, such traditional indicators are not considered appropriate measures of performance for not-for-profit organizations in general and hospitals in particular (Hay, 1990; Ziebell, 1991; Herman, 1994). This is because it is extremely difficult to reliably compare the financial performance of not-for-profit organizations. Since the purpose of these organizations is not

$$
\text { Page -15- }
$$


to generate profit, it would be inappropriate to rate performance based solely on profitability. A hospital's reported satisfaction with financial performance is, therefore, regarded as a reliable measure of financial performance since managers are the ones who have the best familiarity with their organization's relative financial standing.

\section{Data Analysis}

The frequency with which hospital managers used each rationale in developing their organization's mission statement was tabulated. A frequency analysis was also used to determine the extent to which managers believed their organization's mission statement was aligned with their firm's formal structure. A chi-square statistic was calculated in each instance to determine the probability with which the observed frequencies could have occurred by chance. Bivariate correlational analysis was then performed to determine the impact of choosing a particular rationale on each of the five outcome measures. Bivariate correlations were also used to investigate if aligning an organization's formal structure with its mission statement had a relationship with hospital performance.

Page -16- 


\section{The Findings}

\section{Use of Mission Statement Rationales}

Table 2 shows the extent to which hospital managers used each of the ten rationales or drivers when creating their organization's mission statements. The combined "high" and "primary" driver frequency scores were at least 50 percent for seven of the ten rationales. These high-use mission drivers were:

- providing a common purpose;

- defining the scope of the hospital's activities;

- setting behavior standards;

- enabling employees to identify with the hospital;

- promoting shared values;

- addressing needs of external stakeholders; and

- motivating hospital employees.

Of these drivers, there were three which appeared to dominate, i.e., providing a common purpose, defining the scope of the hospital's activities, and promoting shared values. Their "primary driver" frequency scores were at least 50 percent. However, three of the mission statement rationales were also observed to be used considerably less. They were: enabling the CEO to assert control, refocusing the organization during a crisis and providing a basis for resource allocation

The chi-square statistics revealed that the frequencies tabulated were not likely to have occurred by chance. "Refocusing the organization in crisis" and "providing a basis for allocating resources were the only mission rationales whose distribution was not skewed to a significant extent. 
As a sidebar to the main analysis, managers were asked to rate (using a 10 point scale) the degree to which they felt their hospital was actually achieving the various mission statement rationales (which they had previously identified). For the most part, hospital managers believed they were successful in achieving the mission statement rationales - whatever their selection. Additional correlational analysis between the extent to which a rationale was used and its actual achievement also produced vary high results (i.e., all correlations were above .69 and all were significant at the $\mathrm{p}<.001$ level)

\section{Mission Statement Rationales and Hospital Performance}

Table 3 shows the relationship between the various mission rationales and our outcome measures for hospital performance. Five of the rationales were significantly and positively correlated with all five of the performance measures. These rationales were:

to provide a common direction;

$\checkmark \quad$ to promote shared values;

$\checkmark \quad$ to include the interest of key external stakeholders;

$\checkmark \quad$ to motivate/inspire hospital members; and

- to guide resource allocation.

"Enabling the CEO to assert control" and "refocusing during a crisis" were two rationales which did not correlate with the outcome measures to any great extent. 


\section{Mission Statement Alignment with Structural Components}

The frequencies in Table 4 show the extent to which hospital managers believed their hospital's formal structure to be aligned with their mission statement. The majority indicated that their mission statements were either "moderately" or "highly" attuned to their organization's structural components. There were only a few exceptions to this. The organizational components "strategic planning system" and "general business objectives and targets" received the two highest rankings under "high" and "total" mission alignment. "Promotion system" received the two highest rankings under "low" and "moderate" alignment. And "types of rewards" received the two highest rankings under "none" and "low" alignment. It is also noteworthy that very few managers perceived their mission statements to be "totally aligned" in all instances with their hospital's formal organizational arrangements. Interestingly, a separate correlational analysis between the "managers' satisfaction with each organizational component" and "the degree of hospital mission/organization alignment" was also observed to be extremely high (i.e., above .53 and significant at the $p<.001$ level)

In a different analysis, Table 5 shows the correlation between mission/organization alignment and our various hospital performance indicators. In virtually all instances, there was a significantly positive correlation between the alignment measures and the 5 performance outcome measures. The only exceptions were for the components "management information systems" and "choice of technology." These two mission/organization components did not correlate with the outcome measure of "manager's satisfaction with the mission statement", but they did still correlate with the four other performance indicators. 


\section{Discussion and Conclusions}

\section{Mission Statements Rationales in the Not-for-profit Health Care Sector}

The results in Table 2 suggest that hospital managers do indeed have distinct preferences in terms of the rationales they adopt when developing their organization's mission statement. The most frequently stated rationales for mission statements are: "to provide a common direction / purpose", "to define the scope of business", and "to promote shared values". The finding that "providing a basis for allocating resources" was not frequently used as driver was surprising since this is traditionally cited as one of the most important reasons for having a mission statement.

It was particularly fascinating to find that these results were very similar to Bart's (1997a) study of the rationales used for developing mission statements in industrial firms. "Providing purpose", "defining business scope" and "promoting shared values" were each among the primary mission rationales used by managers in these for-profit firms. One interesting difference between the two studies, however, is that managers in the not-for-profit health care sector have a greater consensus on what the top mission drivers should be. For example, the scores for "primary mission drivers" as rated by the managers of industrial firms in Bart's earlier study were only 36.6 percent, 31.0 percent, and 31 percent respectively as compared to 61 percent, 54.5 percent and 52.5 percent as rated by hospital managers. Another similarity is that the mission statement driver of "resource allocation" was also used by the industrial firms to a much lesser extent. This comparison suggests then, that managers of organization's in different industries are developing mission statements for many of the same reasons. But, it also shows that there may be some rationales which vary for

$$
\text { Page -20- }
$$


different industries.

While we observed a high correlation between the "initial motivation behind the creation of the mission" and the achievement of this purpose (Table 2), very few managers believed they were fully achieving any of the mission statement drivers. Part of the reason for this may be timing; it simply takes time to realize the full benefits which formed the primary impetus in its formulation. Another potential reason for this, however, could be the lack of alignment between the mission statement and a firm's formal structure. To the extent that organizational arrangements were not setup to re-enforce the mission, its accomplishment would be "challenging." (The impact of mission statement alignment with a firm's formal structure is discussed later in this paper.) Of course, still other potential reasons for the lack of mission achievement could be related to the mission statement's development process, content or implementation. An investigation and discussion of the importance of these latter concepts was beyond the scope of the current project and is left for future research.

\section{Mission Statements Rationales \& Performance}

The results in Table 3 demonstrate that the more certain rationales are adopted as a basis for mission creation, they more they are associated with higher performance. Five of the mission statement drivers appeared to be particularly important because they varied with all five of our outcome measures. The finding that "providing a common direction /purpose" was a primary driver and impacted performance, however, was not that surprising. Though defining purpose in any business is important, it is vital in a not-for-profit business. Unlike a for-profit business, making money is not an underlying purpose of a nonprofit. Without a stated purpose, it has no reason to exist. Hospital manager's should, therefore, continue to use this as primary driver when formulating

$$
\text { Page -21- }
$$


their organization's mission statement.

It was especially fascinating to find, however, that hospital manager's rarely (16.8 percent) used the driver "to provide a basis for allocating resources." (See Table 2) It was even somewhat alarming because this rational is commonly cited as one of the most fundamental drivers for having a mission statement in the first place. Indeed, we found, that using this driver was strongly associated with superior performance (Table 3). How a firm allocates its resources (i.e., time and money) is one of the most discernable expressions of its strategy. To the extent that administrators don't understand this may explain why so many hospitals have difficulties implementing their mission (strategy).

Moreover, despite the strong relationship that some drivers had with performance, only two of them (i.e., "to provide a common direction / purpose" and "to promote share values") were also "primary rationales" for developing a mission statement. What this suggests is that managers may not be taking full advantage of the power that certain rationales have when developing their hospital's mission. Not all of the mission statement drivers were observed to have the same relationship with the performance measures. Some mission statement drivers are more important than others. Clearly, then, the more that hospital managers emphasize the importance of developing missions to "recognize external stakeholders", "inspire employees", and "allocate resources", the greater the pay-off - at least, in terms of our selected performance measures.

\section{Mission Statement Alignment with Formal Structure}

The frequencies in Table 4 demonstrate that managers align some of their organizational components more with their mission statement than others. They are discriminant in their choices. While it was interesting to observe which organizational components appeared to be highly aligned, 
it was even more fascinating to discover the ones which were being ignored or underplayed. Specifically, the organizational components of "types of rewards" and "promotion system" were found to be less directly tied to mission statements than most of the others. The mean score for the degree of alignment between these components and the mission statement was among the lowest in Table 4. This is intriguing since the reward system is often regarded as one of the most powerful tools for capturing the interest and attention of employees - as well as focusing their efforts.

It was also interesting to examine the organization components which appeared to have the highest degree of mission alignment. These components were "strategic planning system", and "general business objectives and targets." They are not that surprising since the "strategic planning system" is responsible for the development of the mission statement and "general business objectives and targets" typically follow the mission statement.

The results in Table 4, however, also demonstrate the importance of aligning a hospitals' organizational structure with its mission statement. In every case, there was a strong correlation between "organizational alignment with the hospital's mission statement" and "satisfaction with the organizational component." Thus, it appears that the greater the degree of alignment between an organizational component and the mission statement, the more likely hospital managers will be satisfied with and approve of the organizational arrangements. Those managers who were found to have a low degree of mission-organization alignment (particularly on some specific organizational components) would do well to reconsider their current situation.

The results in Table 5, on the other hand, provide overwhelming support for the importance of aligning virtually every organizational dimension with a hospital's mission. In almost every case, a hospital's whose organizational arrangements had been aligned with its mission statement was 
observed to have a powerfully positive association with all of the outcome measures. Most importantly, in every case, the greater the mission/organizational alignment, the higher the satisfaction with financial performance. No component stood out as being more or less important than the others in terms of its relationship with performance. However, as indicated above, managers currently appear to have a distinct preference for emphasizing the alignment between their hospital's mission and certain structural components more than others. (See Table 4) These results suggest, though, that managers should not discriminate (as they appear to do) but rather they should take care to ensure there is a high degree of consistency and fit between their organization's mission statement and all its structural dimensions.

\section{Some Final Thoughts}

Mission statements are frequently used by managers in the not-for-profit health care sector. There is, however, very little guidance which suggests the correct reasons as to why hospital administrators should use them at all. This research study was developed to discover why hospital managers were currently using mission statements and also to determine if some of these reasons mattered more than others. Th project also sought to explore the importance of aligning a hospital's organizational structure with its mission statement.

The findings from this study suggest that managers of not-for-profit hospitals may not always be developing their mission statements for the best reasons. Most notably, few managers are using mission statements to guide the resource allocation process. Not only is this considered a fundamental reason by the historical mission literature, but it was also found in the current study to 
have a substantial impact on hospital performance.

Our research also revealed the importance of aligning a hospital's formal organization with its mission statement. Managers should, therefore, not discriminate, but rather, they should try to align as much of their hospital's structural components with the mission statement as possible. The current findings suggest that the greater the alignment of each organizational component with mission, the greater the impact on performance. This implies that managers should thus consider carefully the results from this study when evaluating or reformulating their hospital's mission statement.

\section{Future Research}

Further research on mission statements in the not-for-profit health care sector is warranted. There are still a number of areas which merit empirical investigation in the future. For example, it would be interesting to look at the impact of the content of a hospital's mission statement on performance. It would also be interesting to examine the importance of the process by which a mission statement is developed and the methods by which it is disseminated in an organization.

Page -25- 


\section{TABLE 1}

\section{Key Operating Statistics}

\begin{tabular}{|l|l|l|}
\hline & $1995($ Mean) & 1994 (Mean) \\
\hline Number of Employees & 1,010 & 964 \\
\hline Revenue & $\$ 53,710,170$ & $\$ 49,653,022$ \\
\hline Súrplus/Deficit & $\$ 115,318$ & $\$ 418,535$ \\
\hline Assets & $\$ 44,291,636$ & $\$ 37,468,404$ \\
\hline
\end{tabular}




\section{TABLE 2}

\section{Use of Mission Statement Rationales}

\begin{tabular}{|c|c|c|c|c|c|c|c|}
\hline $\begin{array}{c}\text { Mission Statement } \\
\text { "Driver"/Rationale }\end{array}$ & $\begin{array}{c}\text { (1) } \\
\text { Not a } \\
\text { Rationale }\end{array}$ & $\begin{array}{c}(2) \\
\text { Low } \\
\text { Rationale }\end{array}$ & $\begin{array}{c}(3) \\
\text { Medium } \\
\text { Rationale }\end{array}$ & $\begin{array}{c}(4) \\
\text { High } \\
\text { Rationale }\end{array}$ & $\begin{array}{c}(5) \\
\text { "Primary" } \\
\text { Rationale }\end{array}$ & Means & $\begin{array}{l}\text { Correlation with } \\
\text { mission driver } \\
\text { achievement }\end{array}$ \\
\hline \multirow{2}{*}{$\begin{array}{l}\text { To provide common } \\
\text { direction/purpose. }\end{array}$} & 1.0 & 2.0 & \multirow[t]{2}{*}{6.0} & 3010 & 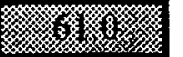 & \multirow[t]{2}{*}{$4.5^{* * *}$} & \multirow[t]{2}{*}{$.55^{* * *}$} \\
\hline & \multicolumn{2}{|c|}{$(3.0)$} & & \multicolumn{2}{|c|}{$1.1 .1 .1 \%$} & & \\
\hline \multirow{2}{*}{$\begin{array}{l}\text { To define scope of } \\
\text { business }\end{array}$} & 0.0 & 7.9 & \multirow[t]{2}{*}{9.9} & $32 \%$. & 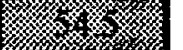 & \multirow[t]{2}{*}{$4.3 * * *$} & \multirow[t]{2}{*}{$.72 * * *$} \\
\hline & \multicolumn{2}{|c|}{ (7.9) } & & \multicolumn{2}{|c|}{$(82 \% 2)$} & & \\
\hline \multirow{2}{*}{$\begin{array}{l}\text { To enable CEO to } \\
\text { assert control }\end{array}$} & 636.6. & 2.8 & \multirow[t]{2}{*}{15.8} & 14.9 & 9.9 & \multirow[t]{2}{*}{$2.4^{* * *}$} & \multirow[t]{2}{*}{$.59 * * *$} \\
\hline & \multicolumn{2}{|c|}{ \% } & & \multicolumn{2}{|c|}{$(24.8)$} & & \\
\hline \multirow{2}{*}{$\begin{array}{l}\text { To create behavior } \\
\text { standards }\end{array}$} & 13.0 & 10.0 & \multirow[t]{2}{*}{15.0} & 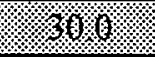 & 20. & \multirow[t]{2}{*}{$3.6 * * *$} & \multirow[t]{2}{*}{$.61^{* * *}$} \\
\hline & \multicolumn{2}{|c|}{$(23.0)$} & & \multicolumn{2}{|c|}{$6.6 \% \%$} & & \\
\hline \multirow{2}{*}{$\begin{array}{l}\text { To enable employees } \\
\text { to identify with firm }\end{array}$} & 9.9 & 8.9 & \multirow[t]{2}{*}{26.7} & (3). & 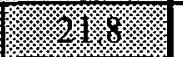 & \multirow[t]{2}{*}{$3.5 * * *$} & \multirow[t]{2}{*}{$.71^{* * *}$} \\
\hline & \multicolumn{2}{|c|}{$(18.8)$} & & \multicolumn{2}{|c|}{ (5\% } & & \\
\hline \multirow{2}{*}{$\begin{array}{l}\text { To promote shared } \\
\text { values }\end{array}$} & 2.0 & 4.0 & \multirow[t]{2}{*}{7.9} & $\$ 3 \% 7 \%$ & 鼡 & \multirow[t]{2}{*}{$4.3 * * *$} & \multirow[t]{2}{*}{$.57^{* * *}$} \\
\hline & \multicolumn{2}{|c|}{$(6.0)$} & & 1918 & \% & & \\
\hline To address needs of & 11.0 & 11.0 & 24.0 & 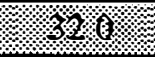 & 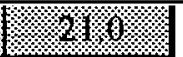 & $3.4^{* *}$ & $.79 * * *$ \\
\hline & $(22$ & .0) & & & $34 \%$ & & \\
\hline To motivate/inspire & 7.8 & 7.8 & 14.7 & x. & 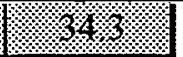 & $3.8 * * *$ & $.76^{* * *}$ \\
\hline emproyees & $(15$ & 6) & & & & & \\
\hline To refocus & 2 & 260 & 18.0 & 21.0 & 14.0 & 2.8 & $.77^{* * *}$ \\
\hline $\begin{array}{l}\text { crisis } \\
\text { chis lin a }\end{array}$ & & 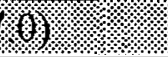 & & & 5.0) & & \\
\hline To provide a basis & $1 / 199$ & 1.. & 24.8 & 27.7 & 16.8 & 3.2 & $.80^{* * *}$ \\
\hline resources & 13 & & & & 4.5) & & \\
\hline
\end{tabular}

\section{Legend:}

* $\quad \mathrm{p}<.05$ (Chi-Square Test for skewness in distribution and Correlations)

$* * \quad \mathrm{p}<.01$

*** $\quad \mathrm{p}<.001$

() combined percentage for two driver ratings 


\section{TABLE 3}

\section{Mission Statement Rationales and Hospital Performance}

\begin{tabular}{|c|c|c|c|c|c|c|}
\hline \multirow[t]{2}{*}{ Mission Statement Rationale } & \multirow[t]{2}{*}{ Means } & \multicolumn{5}{|c|}{ Correlations } \\
\hline & & 1 & 2 & 3 & 4 & 5 \\
\hline A. To provide common direction & 4.5 & $.35^{* * *}$ & $.64^{* * *}$ & $.53^{* * *}$ & $.44^{* * *}$ & $.28^{* * *}$ \\
\hline B. To define scope of business & 4.3 & - & $.30^{* *}$ & - & $.34^{* * *}$ & $.21^{*}$ \\
\hline C. To enable CEO to assert control & 2.4 & - & - & 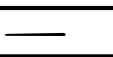 & - & $\overline{-}$ \\
\hline D. To create behavior standards & 3.6 & $.31^{* *}$ & $.43^{* * *}$ & $.35^{* * *}$ & $.31^{* *}$ & $\overline{-}$ \\
\hline $\begin{array}{l}\text { E. To enable employees to identify with } \\
\text { organization }\end{array}$ & 3.5 & $.26^{* *}$ & $.28^{* *}$ & $.32 * * *$ & - & - \\
\hline F. To promote shared values & 4.3 & $.41^{* * *}$ & $.65 * * *$ & $.57^{* * *}$ & $.38^{* * *}$ & $.28 * *$ \\
\hline $\begin{array}{l}\text { G. For the interest of key external } \\
\text { stakeholders }\end{array}$ & 3.4 & $.22 *$ & $.40^{* * *}$ & $.38^{* * *}$ & $.37^{* * *}$ & $.22^{*}$ \\
\hline $\begin{array}{l}\text { H. To motivate/inspire organizational } \\
\text { members }\end{array}$ & 3.8 & $.42^{* * *}$ & $.67^{* * *}$ & $.60^{* * *}$ & $.44^{* * *}$ & $.26^{* *}$ \\
\hline $\begin{array}{l}\text { I. To refocus the organization during } \\
\text { crisis }\end{array}$ & 2.8 & - & $.23^{*}$ & - & - & - \\
\hline J. To guide resource allocation & 3.1 & $.38^{* * *}$ & $.49 * * *$ & $.39 * * *$ & $.39 * * *$ & $.25^{*}$ \\
\hline & & 1 & 2 & 3 & 4 & 5 \\
\hline
\end{tabular}

\section{Legend:}

1. Satisfied with Mission Statement

2. Does MS Influence Respondent?

3. Does MS Influence Others?

4. Are others Committed to MS?

5. Satisfaction with Financial Performance

$\begin{array}{ll}* & \mathrm{p}<.05 \\ * * & \mathrm{p}<.01 \\ * * * & \mathrm{p}<.001\end{array}$




\section{TABLE 4}

\section{Mission/Organizational Structure: Frequencies and Correlation with Satisfaction}

\begin{tabular}{|c|c|c|c|c|c|c|c|}
\hline $\begin{array}{l}\text { Mission/Organizational } \\
\text { Alignment Components }\end{array}$ & $\begin{array}{c}\text { Not } \\
\text { Aligned }\end{array}$ & Low & Moderate & High & $\begin{array}{l}\text { Totally } \\
\text { Aligned }\end{array}$ & $\begin{array}{l}\text { Mean } \\
\text { Score }\end{array}$ & $\begin{array}{l}\text { Corr. With } \\
\text { Component } \\
\text { Satisfaction }\end{array}$ \\
\hline Organizational Structure & 5.3 & 9.6 & ry. & 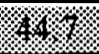 & 18.1 & $3.8^{* * *}$ & $.62 * * *$ \\
\hline Job Descriptions & 12.0 & 15.2 & $\sqrt{3}$ & 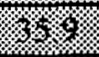 & 9.8 & $3.5 * * *$ & $.55 * * *$ \\
\hline Strategic Planning System & 4.3 & 14.9 & 10.6 & 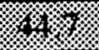 & \%. & $3.8 * * *$ & $.68 * * *$ \\
\hline Operating Planning System & 6.4 & 10.6 & x.1. & $x$ & 17.0 & $3.6 * * *$ & $.68^{* * *}$ \\
\hline Budgeting System & 6.5 & 16.1 & 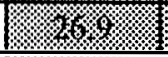 & (3. & 16.1 & $3.5^{* * *}$ & $.65 * * *$ \\
\hline Performance Evaluation Criteria & 12.0 & 22.8 & i. & 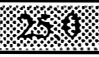 & 8.7 & $3.2 * *$ & $.66^{* * *}$ \\
\hline Types of Rewards & 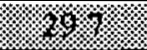 & 2. & 19.8 & 22.0 & 3.3 & $2.7 * * *$ & $.71^{* * *}$ \\
\hline Recruitment System & 13.0 & 18.5 & $(2)$ & 8 & 7.6 & $3.4^{* * *}$ & $.53 * * *$ \\
\hline Promotion System & $18 . \overline{7}$ & \% & 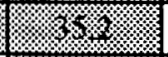 & 19.8 & 1.1 & $3.0 * * *$ & $.66^{* * *}$ \\
\hline $\begin{array}{l}\text { Training/Organizational } \\
\text { Development }\end{array}$ & 8.6 & 16.1 & 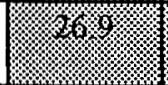 & 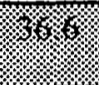 & 11.8 & $3.5 * * *$ & $.68 * * *$ \\
\hline Leadership Styles & 7.6 & 15.2 & r. & צ. & 15.2 & $3.7 * * *$ & $.56 * * *$ \\
\hline $\begin{array}{l}\text { General Business Objectives and } \\
\text { Targets }\end{array}$ & 6.5 & 8.7 & 18.5 & $\sqrt[3]{3}+3.2$ & 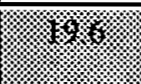 & $3.8^{* * *}$ & $.61^{* * *}$ \\
\hline $\begin{array}{l}\text { Management Information } \\
\text { Systems }\end{array}$ & 17.8 & 20.0 & צr & r. & 4.4 & $2.9 * * *$ & $.67 * * *$ \\
\hline Choice of Technology & 13.3 & 17.8 & 1. & ( & 8.9 & $3.2 * * *$ & $.62 * * *$ \\
\hline
\end{tabular}

\section{Legend:}

* $\quad \mathrm{p}<.05$ (Chi-Square Test for skewness in distribution \& Correlations)

$* * \quad \mathrm{p}<.01$

$* * * \quad \mathrm{p}<.001$ 


\section{TABLE 5}

\section{Mission/Organizational Alignment and Firm Performance}

\begin{tabular}{|c|c|c|c|c|c|}
\hline \multirow{2}{*}{$\begin{array}{l}\text { Mission/Organizational } \\
\text { Alignment Components }\end{array}$} & \multicolumn{5}{|c|}{ Correlations } \\
\hline & 1 & 2 & 3 & 4 & 5 \\
\hline Organizational Structure & $.21^{*}$ & $.42^{* * *}$ & $.46^{* * *}$ & $.61^{* * *}$ & $.39 * * *$ \\
\hline Job Descriptions & $.37^{* * *}$ & $.50^{* * *}$ & $.53^{* * *}$ & $.54^{* * *}$ & $.39 * * *$ \\
\hline Strategic Planning System & $.30^{* *}$ & $.48^{* * *}$ & $.62^{* * *}$ & $.65^{* * *}$ & $.49^{* * *}$ \\
\hline Operating Planning System & $.34^{* * *}$ & $.37^{* * *}$ & $.52^{* * *}$ & $.60^{* * *}$ & $.46^{* * *}$ \\
\hline Budgeting System & $.34^{* * *}$ & $.39 * * *$ & $.50^{* * *}$ & $.57^{* * *}$ & $.43^{* * *}$ \\
\hline Performance Evaluation Criteria & $.30^{* *}$ & $.31^{* *}$ & $.36^{* * *}$ & $.48^{* * *}$ & $.32^{* * *}$ \\
\hline Types of Rewards & $.41^{* * *}$ & $.42^{* * *}$ & $.51^{* * *}$ & $.44 * * *$ & $.31^{* * *}$ \\
\hline Recruitment System & $.42^{* * *}$ & $.40^{* * *}$ & $.42^{* * *}$ & $.53^{* * *}$ & $.34^{* * *}$ \\
\hline Promotion System & $.40^{* * *}$ & $.47^{* * *}$ & $.46^{* * *}$ & $.45^{* * *}$ & $.22^{*}$ \\
\hline $\begin{array}{l}\text { Training/Organizational } \\
\text { Development }\end{array}$ & $.44^{* * *}$ & $.50^{* * *}$ & $.50^{* * *}$ & $.54^{* * *}$ & $.35^{* * *}$ \\
\hline Leadership Styles & $.37^{* * *}$ & $.43^{* * *}$ & $.50^{* * *}$ & $.54^{* * *}$ & $.39^{* * *}$ \\
\hline $\begin{array}{l}\text { General Business Objectives } \\
\text { and Targets }\end{array}$ & $.27^{* *}$ & $.42^{* * *}$ & $.56^{* * *}$ & $.61^{* * *}$ & $.38^{* * *}$ \\
\hline $\begin{array}{l}\text { Management Information } \\
\text { Systems }\end{array}$ & - & $.26^{*}$ & $.27^{*}$ & $.46^{* * *}$ & $.24 *$ \\
\hline \multirow[t]{2}{*}{ Choice of Technology } & - & $.34^{* * *}$ & $.36^{* * *}$ & $.53^{* * *}$ & $.34^{* *}$ \\
\hline & 1 & 2 & 3 & 4 & 5 \\
\hline
\end{tabular}

\section{Legend:}

1. Satisfaction with mission statement

2. Mission statement influence on respondent.

3. Mission influence on others?

4. Commitment to MS?

5. Satisfaction with Financial Performance

$\begin{array}{ll}* & \mathrm{p}<.05 \\ * * & \mathrm{p}<.01 \\ * * * & \mathrm{p}<.001\end{array}$




\section{References:}

Bain \& Company. Management tools and techniques: An executive guide. Bain and Company, Boston, 1994.

Bart, C.K. "Product strategy and formal Structure". Strategic Management Journal, Vol. 7, Iss. 4, July-August, 1986, pp. 283-311. 1986

Bart, C.K. "The impact of mission statements on firm innovativeness." International Journal of Technology Management, Volume 11, Nos 3/4, 1996a.

Bart, C.K. "High tech firms: Does mission matter?" The Journal of High Technology Management Research, Volume 7, Number 2, 1996b, pp. 209-225.

Bart, C.K. "Industrial firms and the power of mission". Industrial Marketing Management, forthcoming, 1997a

Bart, C.K. "A comparison of mission statements \& their rationales in innovative and non-innovative firms", International Journal of Technology Management, forthcoming, 1997b.

Bart, C.K. and Baetz, M.C. "The relationship between mission statements and firm performance: An exploratory study." The Journal of Management Studies, forthcoming 1997.

Bates, D.L. and Dillard, J.E. "Desired future position - A practical tool for planning", Long Range Planning, Vol. 24, June, 1991.

Byars, L.L. Strategic Management: Planning and implementation. Harper and Row, New York, 1984.

Byars, L.L. "Organizational philosophy and mission statements", Planning Review Vol. 15, Iss. 4, pp.32-36, 1987.

Calfee, D. L. “Get your mission statement working!” Management Review, January 1993, pp. 54-57.

Campbell, A. "Does your organization need a mission?", Leadership and Organization Development, Vol. 3, 1989.

Campbell, A. and Yeung, S. "Creating a sense of mission", Long Range Planning. Vol. 24, Iss. 4, 1991, pp. 10-20.

Campbell, A. "The power of mission: Aligning strategy and culture", Planning Review, Special Issue, 1993.

Page -31- 


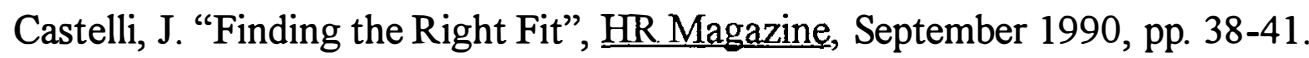

Coats, J., Davis, E., Longden, S., Stacey, R. and Emmanuel, C. "Objectives, missions and performance measures in multinationals", European Management Journal, Vol. 9, Iss. 4, December 1991.

Collins, J.C. and Porras, J.I. "Organizational vision and visionary organizations", California Management Review, Fall, 1991.

Collins, J.C. and Porras, J.I. Built to last, Harper Business, New York; 1994.

Daniel, A.L. "Strategic Planning - The role of the chief executive", Long Range Planning, Vol. 25, April, 1992.

Daft R.L. and Fitzgerald, P.A. Management. Dryden Canada, Toronto, 1992.

Darazsdi, J. J. “Viewpoint-Mission Statements are Essential", Personnel Journal, February 1993, pp. 24-25.

David, F.R. Strategic Management, Fourth edition. Macmillan: New York, 1993.

David, F.R. "How companies define their mission", Long Range Planning. Vol. 22, Iss. 1, pp. 1989, pp. 90-97.

Drucker, P. Management: Tasks, responsibilities and practices. Harper and Row, New York, 1974.

Drucker, P. "What Business Can Learn from Nonprofits." Harvard Business Review, July-August 1989, pp 88-93.

Dust, B. "The Business of Training-Making Mission Statements Meaningful." Training \& Development, June 1996, pg. 53

El-Namaki, M.S.S. "Creating a corporate vision", Long Range Planning, Vol. 25, December, 1992.

Galbraith, J.R. and Kazanjian, R.K. Strategy implementation: Structure, systems and process, Second Edition. St Paual:MN: West Publishing, 1986.

Germain, R. and Cooper, M.B. "How a customer mission statement affects company performance," Industrial Marketing Management, Vol. 19, 1990.

Hamermesh, Richard G. "Note on Implementing Strategy", President and Fellows of Harvard College, 1982. 
Hay, Robert D. Strategic Management in Non-Profit Organizations: An Administrator's Handbook. Quorum Books, NY, 1990.

Herman, Robert D. The Jossey-Bass Handbook of Nonprofit Leadership \& Management. JosseyBass Publishers, San Francisco, 1994.

Higgins, J.W. and Vincze, J.W. Strategic Management-Text and Cases. The Dryden Press, New York, 1989.

Holland, P.G. and Rue, L.W. Strategic Management-Concepts and Experiences. McGraw Hill, New York, 1989.

Ireland, RD. and Hitt, M.A. "Mission statements: Importance, challenge and recommendations for development", Business Horizons. 35, 3, May-June, 1992, pp. 34-42.

Javidan, M. "Leading a high-commitment high-performance organization", Long_Range Planning, Vol. 24, 1991.

Johnson, G. Scholes, K. Sexty, R.W. Exploring Strategic Managament, Prentice Hall Canada, Scarborough, 1989.

King, W.R. and Cleland, D.I. Strategic planning and policy, van Nostrand Reinhold, New York, 1979.

Klemm, M., Sanderson, S. and Luffman, G. "Mission statements: Selling corporate values to employees", Long Range Planning, Vol. 24, No.3, pp.73-78, 1991.

Krohe Jr., J. "Do you really need a mission statement?" Across the Board, July/August, 1995, pp. 17-21.

Lawrence, P. and Lorsch, J. Organization and environment: Managing differentiation and integration. Harvard University, 1967.

McGinnis, V.J. "The mission statement: A key step in strategic planning", Business, NovemberDecember, 1981, pp. 39-43,

Medley, G.J. "WWF UK creates a new mission", Long Range Planning, Vol. 25, April, 1992, pp. 63-68.

Moldof, Edwin P. "Do-it-yourself strategic planning provides map to the future." Healthcare Financial Management, February 1994, pp. 27-31.

Nelton, S. "Put your purpose in writing; a mission statement can give your company the focus

$$
\text { Page -33- }
$$


it needs for survival and growth." Nation's Business, Volume 82., Issue 2, February 1994, pp 61-64.

Rumelt, R. P. Strategy structure and economic performance. Harvard University, 1974.

Sandstrom, R. "Development of a comprehensive staff education plan for a rehabilitation center." Health Care Supervisor, Vol. 13, Issue 2, pp. 34-43.

Sion, M. "Provost gives his take on how to reengineer health care." Drug Topics, August 5, 1996, pg. 30

Stone, R. A. "Mission Statements Revisited", SAM Advanced Management Journal, Winter 1996, pp. 31-37.

Thompson, A.A. and Strickland, A.J. Strategic Management: Concept and cases, Ninth edition. Irwin: Illinois, 1996.

Want, J.H. "Corporate mission", Management Review, August, 1986, pp. 46-50.

Wheelen, T. J. and Hunger, J.D. Strategic management and business policy, Fourth edition. Addison-Wesley: New York, 1992.

Wilson, I. "Realizing the power of strategic vision", Long Range Planning, Vol. 25, Iss. 5, 1992. pp. $18-28$.

Ziebell, Mary T. and De Costes, Don T. Management Control Systems in Nonprofit Organizations. Harcourt Brace Jovanovich, Publishers, San Diego, 1991. 


\section{Faculty of Business \\ McMaster University \\ WORKING PAPERS - RECENT RELEASES}

395. Roy Adams, "A Pernicious Euphoria: 50 Years of Wagnerism in Canada", November, 1994.

396. Roy Adams, "The Determination of Trade Union Representativeness in Canada and the United States", November, 1994.

397. Shouhong Wang, Norman P. Archer, "A Fuzzy Decision Making Model", December, 1994.

398. Kalyan Moy Gupta and Ali R. Montazemi, "A Methodology for Evaluating the Retrieval Performance of Case-Based Reasoning Systems", December, 1994.

399. Jiang Chen and George Steiner, "Lot Streaming with Detached Setups in Three-Machine Flow Shops", December, 1994.

400. Jiang Chen and George Steiner, "Lot Streaming with Attached Setups in Three-Machine Flow Shops", December, 1994.

401. Ali R. Montazemi and Feng Wang, "An Empirical Investigation of CAI in Support of Mastery Leaming", February, 1995.

402. Kalyan Moy Gupta and Ali Reza Montazemi, "Retrieval in Case-Based Reasoning Systems with Modified Cosine Matching Function", February, 1995.

403. Kalyan Moy Gupta and Ali Reza Montazemi, "A Connectionist Approach for Similarity Assessment in Case-Based Reasoning Systems", March, 1995.

404. John W. Medcof, "Selecting Alliance and Network Partners - Strategic Issues", March 1995.

405. Jiang Chen and George Steiner, "Discrete Lot Streaming in Two-Machine Flow Shops", March, 1995.

406. Harish C. Jain and S. Muthuchidambaram, "Strike Replacement Ban in Ontario and Its Relevance to U.S. Labor Law Reform", May, 1995.

407. Ali R. Montazemi and Kalyan Moy Gupta, "A Framework for Retrieval in Case-Based Reasoning Systems", June, 1995. 
408. Ali R. Montazemi and Kalyan Moy Gupta, "An Adaptive Agent for Case Description in Diagnostic CBR Systems", June, 1995.

409. Roy J. Adams, Noel Cowell and Gangaram Singh, "The Making of Industrial Relations in the Commonwealth Caribbean", June, 1995.

410. Jiang Chen and George Steiner, "Approximation Methods for Discrete Lot Streamingin Flow Shops", June, 1995.

411. Harish C: Jain and S. Muthuchidambaram, "Bill 40 Amendments to Ontario Labour Relations Act: An Overview and Evaluation", June, 1995.

412. Jiang Chan and George Steiner, "Discrete Lot Streaming in Three-Machine Flow Shops", July, 1995.

413. J. Brimberg, A. Mehrez and G.O. Wesolowsky, "Allocation of Queueing Facilities Using a Minimax Criterion", January, 1996.

414. Isik Zeytinoglu and Jeanne Norris, "Global Diversity in Employment Relationships: A Typology of Flexible Employment", March, 1996.

415. N. Archer, "Characterizing World Wide Web Search Strategies", April, 1996.

416. J. Rose, "Immediacy and Saliency in Remedying Employer Opposition to Union Organizing Campaigns", July, 1996.

417. Roy J. Adams and Parbudyal Singh, "Worker Rights Under NAFTA: Experience With the North American Agreement on Labor Cooperation", September, 1996.

418. George Steiner and Paul Stephenson, "Subset-Restricted Interchange for Dynamic MinMax Scheduling Problems", September, 1996.

419. Robert F. Love and Halit Uster, "Comparison of the Properties and the Performance of the Criteria Used to Evaluate the Accuracy of Distance Predicting Functions", November, 1996.

420. Harish C. Jain and Simon Taggar, "The Status of Employment Equity in Canada", December, 1996.

421. Harish C. Jain and Parbudyal Singh, "Beyond The Rhetoric: An Assessment of the Political Arguments and Legal Principles on Strike Replacement Laws in North America", January, 1997.

422. Jason Schwandt, "Electronic Data Interchange: An Overview of Its Origins, Status, and Future", March, 1997. 
Innis Ref.

$H B$

74.5

.847

no. 423

c. 1 